\section{More on nutrition}

SIR,-Since I participated in what Rivers says may have been the "golden age" of nutrition, I feel that I should comment on his indictment (January 10). He says that since 1945 , "nutrition in the UK has been neither of military importance nor Nobel Prize ranking." The first circumstance is difficult to deplore since it mainly results from the lack of World War III; the second criticism is tinged with nostalgia. Rivers apparently expects nutritionists to produce miraculous "cures" of "obesity, diabetes mellitus, kwashiorkior, ischaemic heant disease and many of the other great nutritional [sic] scourges." He suggests that the reason that these cures have not appeared is the lack of an experimental animal with an evolutionary defect such as the loss of $\mathrm{L}$ gulonolactone oxidase in the guinea pig. In other words, he thinks that these "scourges" are deficiency diseases awaiting the discovery of an ascorbic acid. But much obesity results from over-eating, only occasionally aggravated by endocnine imbalance; diabetes mellitus comes from hormonal insufficiency; and kwashiorkor from economic, cultural and environmental deprivation. Whether ischaemic heart disease is a nutritional deficiency is not known.

Rivers says that "we do not know why nutrition education fails when advertising works". But, alas, we do and this sentence is the keynote to Rivers' lack of understanding of the predicament of nutrition. This is the day of the nutritional pied piper. The story of scientific nutrition is too humdrum to attract popular attention, at least in the USA, in the fierce light of competition from the writings and speeches of Adelle Davis, Carlton Fredericks, Linus Pauling, Jerome Rodale, Doctor Atkins, R. J. Williams and the brothers Shute who promise relief from heart disease, cancer, infections, prostate trouble, obesity, shortness of life, and back pains by devouring pumpkin seeds, raw milk, dried seaweed, ascorbic acid, fertilised eggs, apricot seeds, vitamin $\mathrm{E}$ and garlic, or by not consuming white bread, pasteurised milk and food additives. As Philip White of the American Medical Association says, "what usually happens is that the scientific spokesman ends up sounding like a close-minded Establishment bore who wants to suppress bright new ideas".
Nutritionists wearily spend their time trying to pick up the pieces in the wake of this ideological hurricane. Yes, we know too well that advertising works. Rivers kindly informs us that we "are not in business to pursue uncluttered academic research" (where have scientists heard this before and how does Rivers expect a remedy for ischaemic heart disease without research?) "but to improve the nutritional status of the population", to do which we "don't know how". It sounds as if he doesn't know what he is talking about. One thing we do not need is more Nobel laureates, especially loquacious ones. We have the tremendous task of applying the knowledge of nutrition to the needs of a species that is fantastically eccentric and variable in its attitude towards the acceiptability of food, and that is increasingly influenced by nutritional nonsense dispensed by the mass media. The task is made frustrating by the fact that the annual bulk cost for supplying the needed allowances for ten vitamins and eight essential minerals is less than \$1 per capita, but for socioeconomic political and logistic reasons, we cannot get them to most people. On top of this, we are faced by the awesome world food crisis. There is little helpfulness in Rivers's fuzzy sermonising. There is need for calories and there is no alternative to photosynthesis.

\section{Berkeley, California}

$$
\text { Thomas H. Jukes }
$$

\section{Peaceful explosions}

Sir, - That the Non-Proliferation Treaty has defects, to some of which you have drawn attention, is widely accepted, but to adapt a well-known phrase, it is the best treaty we have. Roughly two-thirds of UN states are full parties to the treaty, which requires states to refrain from policies many of them would otherwise actively pursue.

Your particular complaint that nothing has been done to implement the requirements of Article $V$, that there should be an international organisation for the provision of peaceful nuclear explosions to non-nuclear weapon states, is not strictly correct. On the recommendation of the Conference of Non-Nuclear Weapon States in 1968, the UN General Assembly agreed in 1971 that the International Atomic Energy Agency itself should assume that responsibility. So far Czechoslovakia, Madagascar and Romania have enquired about services, but a specific proposal is yet to come.

This does not mean that peaceful nuclear explosions will not be a contentious issue at the Review Conference in May, but the issues will be different from those you suggest. Now that Congress has for practical purposes put an end to the Plowshare programme, and as it becomes clearer that the Russian programme of peaceful explosions, however extensive, is yielding disappointing results, the nuclear powers will be tempted to suggest that nonnuclear parties should forego peaceful explosions. Politically that would be dangerous; let non-nuclear states discover economic reality for themselves.

That the treaty is for practical purposes innocent of security assurances for non-nuclear weapon states is true enough, as your leading article says, but it could hardly be otherwise. In practice, the best way of achieving this goal is along the lines of the LatinAmerican denuclearisation treaty (the Treaty of Tlatelolco, 1967). Indeed, there is good evidence that states unwilling to accede to the NPT will take part in regional arrangements like this. Although the main defect of the treaty is, as you say, that it asks for "minimal concessions" from the nuclear powers, it does require of them rapid progress towards a comprehensive test-ban treaty and measures for the reduction of nuclear stockpiles. Indeed, the NPT is a compact between non-nuclear states and nuclear states in which the former undertake to refrain from "horizontal" proliferation and the latter to pursue nuclear arms control. Much of the argument at the review conference will no doubt hinge on the extent to which the superpowers can fob off their critics with the Threshold Test-Ban agreement and SALT II. Probably they will not succeed. There will be pressure for more effective means of monitoring the super-powers than five-year reviews provide.

Precisely for this reason, the NPT is a potentially important forum within which measures of nuclear arms control can be developed. At the same time, there are many significant ways in which the inequalities of the treaty can be softened, not necessarily within its legal structure. To "suggest the treaty be scrapped and new approaches tried" is to run the risk of setting back arms control for a decade or more.

London EC4, UK
John MADDOX 